\title{
Economic feasibility of summer squash cultivation using low tunnel and black plastic mulch under tarai condition of Uttarakhand
}

\author{
Lalit Bhatt*, S.K. Maurya and Dhirendra Singh \\ Pantnagar-263 145, U. S. Nagar (Uttarakhand), INDIA \\ *Corresponding author. E-mail: drbhattlalit@gmail.com \\ Received: June 28, 2015; Revised received: January 28, 2016; Accepted: May 19, 2016
}

Department of Vegetable Science, College of Agriculture, G. B. Pant University of Agriculture \& Technology,

\begin{abstract}
A study was undertaken to investigate the economic feasibility of summer squash cultivation in tarai region of Uttarakhand during winter - spring season of 2013-14 and 2014-15. Among three transplanting dates, summer squash transplanted on $15^{\text {th }}$ January was found to be best with respect to plant growth characters, total yield (373.50 q ha $\left.{ }^{-1}\right)$, net return $\left(2,46,542 \mathrm{ha}^{-1}\right)$ and benefit - cost ratio (2.72). Similarly, out of three low cost protected techniques evaluated along with control, low tunnel with black plastic mulch was observed as best with respect to plant growth characters, total yield $\left(451.67 \mathrm{q} \mathrm{ha}^{-1}\right)$. Whereas, the maximum net return $\left({ }^{\prime} 2,87,628 \mathrm{ha}^{-1}\right)$ and benefit - cost ratio (3.58) was obtained in black plastic mulched plots. Out of 12 treatment combinations, summer squash planted on $15^{\text {th }}$ January under black polyethylene mulch is most profitable in terms of getting maximum benefit - cost ratio of 4.41 . Hence, the same is recommended for commercial cultivation of summer squash at farmer's field under tarai condition of Uttarakhand.
\end{abstract}

Keywords: Cucurbita pepo, Economics, Low tunnel, Plastic mulch, Summer squash

\section{INTRODUCTION}

Summer squash botanically known as Cucurbita pepo L., is one of the important quick growing and early yielding cucurbitaceous vegetable known by different names viz., chappan-kaddu, bush squash, common field pumpkin and vegetable marrow. Though in India, summer squash is not very popular but grown on a limited scale in Punjab, Delhi, Uttar Pradesh, Himachal Pradesh and hills of Uttarakhand. Summer squash performs well in mild weather conditions (16$27^{\circ} \mathrm{C}$ ), high relative humidity and bright sunshine are also ideal for squash cultivation. It is a compact bushy plant, in which the tendrils have been reduced in size and function. Ease in cultivation, quick growth, high yield and off season nature of crop lead to higher return per unit area under small and scattered land holding, thus attracting small and marginal vegetable growers toward its cultivation (Bhatt et al., 2011).

Although the climatic conditions of tarai region of Uttarakhand is not suited for summer squash cultivation under open condition due to unfavourable temperature during growth period and shorter growing period. However, summer squash can be successfully cultivated under protected condition and fruits are sold at premium price as no other cucurbit is available in the market during that period. The major restrictive factor for summer squash cultivation in polyhouse is high cost of cultivation and poor economic condition of majority of farmers. However, summer squash culti- vation can be made profitable for small and marginal farmers by modification of microclimatic condition using low cost protected cultivation techniques like plastic mulch and low tunnels. Mulching with plastic films modifies the soil temperature, moisture regimes and also control weeds (Singh et. al., 2014). Amongst the different colored plastic film, mulching with black plastic has been found most efficient. Plastic low tunnels are miniature greenhouse-like structures approximately 60 to $100 \mathrm{~cm}$ high and 75 to $100 \mathrm{~cm}$ wide at the base and are erected with wire hoops or flexible wood or bamboo and covered with clear plastic. The tunnel warms the air surrounding the plants, using heat from the sun. The tunnels also protect plants from frost damage. Plastic low tunnels have great potential because they are cheap to construct, can be removed during the dry season (Lodhi et al., 2013). Thus, considering the importance of summer squash as potential cucurbit of Uttarakhand and to diversify the vegetable cultivation, the present study was planned to find out the best low cost protected technology to make the summer squash cultivation a profitable business for small and marginal farmer of the region.

\section{MATERIALS AND METHODS}

The present study was carried out during winter spring seasons of 2013-14 and 2014-15 at Vegetable Research Centre of G.B.P.U.A.\&T., Pantnagar. The 
experimental site lies in 'tarai' plains of foot hills of Shivalik range of Himalayas at $29^{\circ} \mathrm{N}$ latitude, $79.29^{\circ} \mathrm{E}$ longitudes and an altitude at $243.8 \mathrm{~m}$ above mean sea level. The experiment was laid out in Two Factorial Randomized Block Design with four replications. The first factor include three transplanting dates i.e. $15^{\text {th }}$ November $\left(D_{1}\right), 15^{\text {th }}$ December $\left(D_{2}\right)$ and $15^{\text {th }}$ January $\left(D_{3}\right)$, whereas the second factor comprises of three low cost protected cultivation techniques i.e. black plastic mulch along with low tunnel $\left(\mathrm{T}_{2}\right)$, black plastic mulch $\left(\mathrm{T}_{3}\right)$ and low tunnel $\left(\mathrm{T}_{4}\right)$ were compared with unmulched control $\left(\mathrm{T}_{1}\right)$. The experimental plot along with FYM@25 t/ha were supplied with fertilizers in the form of NPK @ 120, 100 and 80 kg ha ${ }^{-1}$, respectively. The seedlings raised in polybags were transplanted at respective dates in the plot of $10 \mathrm{~m} \times 1.00 \mathrm{~m}$ size at a spacing of $1.00 \mathrm{~m} \times 0.75 \mathrm{~m}$. The plots were mulched with black plastic film of $25 \mu$ thickness one day before transplanting, where as low tunnels were erected day after transplanting using low cost bamboo sticks. Observations for growth and yield attributes were recorded using standard techniques. The economics of summer squash was worked out based on inputs and operational cost incurred since seed sowing to harvest of fruits including marketing. The data recorded for both the year was analyzed using statistical methods suggested by Panse and Sukhatme (1989) and pooled data is presented in tables.

\section{RESULTS AND DISCUSSION}

Growth and flowering: Data for various parameters presented in table 1 clearly revealed that different transplanting dates and low cost protected cultivation technologies like plastic mulch and low tunnels significantly affected the growth, flowering and yield of summer squash. Significantly wider plant spread of 103.00 $\mathrm{cm}$ was recorded in summer squash transplanted on $15^{\text {th }}$ January in comparison to previously transplanted plants. Plastic mulch in combination with low tunnel increased the plant spread $(112.80 \mathrm{~cm})$ by the order of $81.93 \%$ than open field cultivation whereas, low tunnel alone increases it by $70.16 \%$ and plastic mulch alone increases it by the order of $42.50 \%$ compared to control and all the low cost technology tested differed significantly than open field cultivation of summer squash. Interactive effect of both the factor i.e. low cost protected cultivation techniques and transplanting dates reveals significantly wider plant spread (122.00 $\mathrm{cm}$ ) compared to the other treatments when summer squash was transplanted in low tunnel mulched with black plastic and transplanted on $15^{\text {th }}$ January. Data pertaining to days to $50 \%$ flowering (Table 1) reveals that earliest flowering i.e. minimum number of days to $50 \%$ flowering (24.58) in summer squash was observed with $15^{\text {th }}$ November planting followed by $15^{\text {th }}$ January (30.83) and $15^{\text {th }}$ December (35.08). Amongst the different low cost protected techniques, earliest flowering (26.56) were observed in plants mulched with black plastic grown under low tunnel plants and was at par with low tunnel (27.67), while it was significantly better than plants grown under black plastic film (30.78) and open cultivation (35.67) at probability of 0.05 . On the other hand in the interaction effect of twelve treatment combinations reveals that minimum day taken to $50 \%$ flower formation (22.67) were noted in treatment combination comprises of low tunnel having black plastic mulch planted on $15^{\text {th }}$ November. The increase in vegetative growth observed with $15^{\text {th }}$ January planting was attributed to favourable moderate temperature as per crop requirement available for growth and development of summer squash, whereas lower temperature restrict the growth and development of early planted crop. Of the different low cost protected cultivations techniques evaluated during the study, use of low tunnel along with black plastic mulch recorded maximum vegetative growth and earliest flowering due to higher photosynthesis and other metabolic activity under favorable microclimate in terms of temperature around plant, soil and optimum soil moisture promoted better growth and early flowering. Salman et al. (1992) also observed that increase in soil temperature was observed under both plastic mulch and tunnel, and higher temperature promoted early vegetative growth and flowering compared to open field condition. Singh et al. (2005) reported better vegetative growth of plants under plastic films may be

Table 1. Effect of transplanting dates and low cost protected techniques on growth, flowering and yield of summer squash (Pooled data of both the year).

\begin{tabular}{|c|c|c|c|c|c|}
\hline Treatments & $\begin{array}{l}\text { Plant spread } \\
(\mathrm{cm})\end{array}$ & $\begin{array}{l}\text { Days to } 50 \% \\
\text { flowering }\end{array}$ & $\begin{array}{l}\text { Days to first } \\
\text { harvest }\end{array}$ & $\begin{array}{l}\text { Total crop } \\
\text { duration (Days) }\end{array}$ & $\begin{array}{l}\text { Total yield } \\
\left(\mathrm{q} \mathrm{ha}^{-1}\right)\end{array}$ \\
\hline \multicolumn{6}{|l|}{ Dates of transplanting } \\
\hline $15^{\text {th }}$ November $\left(\mathrm{D}_{1}\right)$ & 94.66 & 25.58 & 46.17 & 101.50 & 284.72 \\
\hline $15^{\text {th }}$ December $\left(\mathrm{D}_{2}\right)$ & 80.74 & 36.08 & 49.00 & 107.08 & 333.38 \\
\hline $15^{\text {th }}$ January $\left(\mathrm{D}_{3}\right)$ & 103.00 & 31.83 & 49.00 & 84.33 & 373.51 \\
\hline $\mathrm{CD}$ at $5 \%$ & 2.57 & 1.23 & 1.40 & 2.03 & 28.54 \\
\hline \multicolumn{6}{|c|}{ Low cost protected cultivation technique used } \\
\hline Control $\left(\mathrm{T}_{1}\right)$ & 62.00 & 36.67 & 58.55 & 91.44 & 106.32 \\
\hline Black plastic mulch and low tunnel $\left(\mathrm{T}_{2}\right)$ & 112.80 & 27.56 & 43.22 & 103.00 & 451.67 \\
\hline Black mulch $\left(\mathrm{T}_{3}\right)$ & 88.35 & 31.78 & 43.00 & 101.44 & 412.05 \\
\hline Low tunnel $\left(\mathrm{T}_{4}\right)$ & 105.50 & 28.67 & 46.11 & 94.78 & 352.12 \\
\hline $\mathrm{CD}$ at $5 \%$ & 2.23 & 1.26 & 1.21 & 1.85 & 25.60 \\
\hline
\end{tabular}


Table 2. Interaction effect of transplanting dates and low cost protected techniques on growth, flowering and yield of summer squash (Pooled data of both the year).

\begin{tabular}{llllll}
\hline $\begin{array}{l}\text { Treatments } \\
\text { combinations }\end{array}$ & $\begin{array}{l}\text { Plant spread } \\
\text { (cm) }\end{array}$ & $\begin{array}{l}\text { Days to 50\% } \\
\text { flowering }\end{array}$ & $\begin{array}{l}\text { Days to first } \\
\text { harvest }\end{array}$ & $\begin{array}{l}\text { Total crop duration } \\
\text { (Days) }\end{array}$ & $\begin{array}{l}\text { Total yield (q } \\
\text { ha }^{-1} \text { ) }\end{array}$ \\
\hline $\mathrm{D}_{1} \mathrm{~T}_{1}$ & 64.33 & 28.43 & 57.33 & 99.12 & 87.45 \\
$\mathrm{D}_{1} \mathrm{~T}_{2}$ & 118.67 & 23.76 & 39.67 & 105.00 & 415.66 \\
$\mathrm{D}_{1} \mathrm{~T}_{3}$ & 91.60 & 26.10 & 45.33 & 101.33 & 305.75 \\
$\mathrm{D} 1 \mathrm{~T}_{4}$ & 104.30 & 24.33 & 42.33 & 102.72 & 320.05 \\
$\mathrm{D}_{2} \mathrm{~T}_{1}$ & 55.00 & 42.35 & 52.25 & 105.33 & 80.56 \\
$\mathrm{D}_{2} \mathrm{~T}_{2}$ & 101.35 & 31.16 & 49.00 & 111.76 & 495.32 \\
$\mathrm{D}_{2} \mathrm{~T}_{3}$ & 74.30 & 38.75 & 36.67 & 111.35 & 395.35 \\
$\mathrm{D}_{2} \mathrm{~T}_{4}$ & 93.60 & 32.67 & 52.00 & 107.00 & 352.32 \\
$\mathrm{D}_{3} \mathrm{~T}_{1}$ & 68.33 & 39.33 & 59.00 & 82.16 & 150.97 \\
$\mathrm{D}_{3} \mathrm{~T}_{2}$ & 122.00 & 28.00 & 44.15 & 92.00 & 440.04 \\
$\mathrm{D}_{3} \mathrm{~T}_{3}$ & 103.40 & 31.82 & 50.24 & 92.13 & 495.05 \\
$\mathrm{D}_{3} \mathrm{~T}_{4}$ & 118.75 & 29.10 & 47.62 & 87.33 & 384.00 \\
$\mathrm{CD}$ at $5 \%$ & 4.46 & 2.11 & 2.32 & $\mathrm{NS}$ & 45.18 \\
\hline
\end{tabular}

attributed to more $\mathrm{CO}_{2}$ available for photosynthesis due to chimney effect as plastic mulches are impervious to carbon dioxide resulting in abundant $\mathrm{CO}_{2}$ for plants which have resulted in higher plant growth and development. Similarly, Bhatt et al. (2011) also noticed that the use of black plastic much increased the plant spread by $22.4 \%$ and advanced the flowering time by four to five days in summer squash under favourable climatic condition of mid-hills of Uttarakhand during summers, while under unfavourable climatic condition of tarai during winter use of black plastic mulch increase the spread of plant by $42.5 \%$ and use of mulch along with plastic tunnel the increase in spread by $82.0 \%$ during the present study.

Yield and yield attributes: Positive influence of planting dates, low cost protected cultivation techniques tested during the studied and their interaction was noticed for early fruit harvest, crop duration and fruit yield of summer squash. Delaying the transplanting time from $15^{\text {th }}$ November to $15^{\text {th }}$ January delays the earliness by four days, of which $15^{\text {th }}$ December and $15^{\text {th }}$ January took 49 days to first harvest in both. Similarly, use of black plastic mulch in combination with low tunnel advanced the harvesting time by 15 days compared to control (58.55). Interactive effect of these two factors reveals the significantly lesser number of days were taken by combination of these factors compared to other treatments whereas, non significant effect was recorded for total crop duration. Mulching with black polyfilm in plastic low tunnel took minimum days to first harvest when transplanted on $15^{\text {th }}$ November (39.67), whereas transplanting of summer squash on $15^{\text {th }}$ January under open condition took maximum (59) days (Table 2). Increase in yield was also observed with increasing the planting time form $15^{\text {th }}$ November $(301.89 \mathrm{q} / \mathrm{ha})$ to $15^{\text {th }}$ January $(387.32 \mathrm{q} /$ ha), whereas planting on $15^{\text {th }}$ December and $15^{\text {th }}$ January was at par with this respect (Table 1). Similarly, black plastic mulch in combination with low tunnel ( $451.67 \mathrm{q} / \mathrm{ha})$ increased the yield by 4.24 times than open field planting $(106.32 \mathrm{q} / \mathrm{ha})$. While the use of low tunnel (352.12 q/ha) and black plastic mulch (412.05 $\mathrm{q} /$ ha) alone increase the yield by 3.31 and 3.87 times compared to open field control in this regard. Among twelve treatment combinations presented in table 2 , the maximum crop duration and total yield (495.32 q/ha) were recorded in summer squash grown in low tunnel having black plastic mulch with $15^{\text {th }}$ December transplanting and was 5.66 times higher over open field grown squash planted on $15^{\text {th }}$ November under open condition. The increase in yield and duration of cropping period observed with different transplanting dated was attributed to the favorable microclimate for growth and development during the crop period. Whereas, increase in fruit yield per plant by using low cost protected structures might be on account of higher vegetative growth due to rise in soil temperature and better microclimate promoting higher photosynthesis due to more uptakes of nutrients. Hence in this situation dry matter accumulation and partitioning was better at different plants parts, which lead to higher yield. Treatments having both low tunnel and black plastic mulch were observed better than their individual's effect. These results have similarities with the findings of Pimpini et al. (1987) in which, mulch and tunnel increased the yield of tomato by $54 \%$ of which $25 \%$ increase in yield occur during first four harvest. Higher yield of pepper due to increase in soil temperature under plastic tunnel was also observed by Gerber et al. (1988). Abak et al. (1990) recorded increase in yield of pepper (21\%), eggplant (21\%), melon (67\%) and water melon $(98 \%)$ by application of plastic mulch.

Economic feasibility: The data indicated in table 3 shows that the maximum cultivation cost of ' $1,29,873$ $\mathrm{ha}^{-1}$ in this study was incurred in $15^{\text {th }}$ January transplanting planting. Similarly, higher cultivation cost of summer squash ( $1,85,090 \mathrm{ha}^{-1}$ ) was worked out in treatment having low tunnel with black plastic mulch and was 2.44 times higher compared to open cultivation i.e. traditional practices $(75,954)$. The gross and net returns in different planting dates, low cost protected techniques and combinations of both of these were worked out based on prevalent wages, rate of 
critical inputs and average selling price of produce. Among the three planting dates, highest gross return $\left(` 3,57,915 \mathrm{ha}^{-1}\right)$, net profit $\left(2,46,542 \mathrm{ha}^{-1}\right)$ and benefit - cost ratio (2.75) were obtained in $15^{\text {th }}$ January transplanting however, among the three low cost protected techniques tested in this study, black polyethylene mulch in combination with low tunnel showed maximum gross return of $4,50,440 \mathrm{ha}^{-1}$. While, the maximum net return $\left(2,87,628 \mathrm{ha}^{-1}\right)$ and benefit: cost ratio of 3.58 was obtained in treatment having black plastic mulch alone. Among different treatment combinations, transplanting of summer squash on $15^{\text {th }}$ January using black plastic mulch was observed as best in getting maximum gross $(4,95,350)$, net return $\left({ }^{`} 3,83,228\right)$ and benefit - cost ratio (4.41). The increased net return and higher benefit - cost ratio under different planting dated were attributed due to higher fruits yield. The higher value for gross and net return in treatment having black plastic mulch under low tunnel could be due to higher fruit yield leading to higher net and gross yield. Similar to the present study, Bhatt et. al. (2011) also observed higher $\mathrm{B}: \mathrm{C}$ ratio 2.61 using the black plastic mulch compared to 1.79 under open field condition. Whereas, in present study open field condition of summer gave the $\mathrm{B}: \mathrm{C}$ ratio of 1.39 and was increased to 3.58 under black plastic mulch and 2.53 using plastic tunnel alone. Higher benefit - cost ratio under observed in black plastic mulch compared to tunnel and tunnel having black plastic mulch (2.23) was due additional cost required in erection of low tunnel. Growing of summer squash using low cost protected techniques resulted in much higher yield and profit irrespective of planting dates compared to those grown in open field.

\section{Conclusion}

Based on the findings of present investigation, it could be concluded that under tarai condition of Uttarakhand summer squash transplanted on $15^{\text {th }}$ January under black polyethylene mulch is most profitable in terms of getting maximum benefit cost ratio of 4.41. Hence, the same is recommended for commercial cultivation of summer squash at farmer's field under tarai condition of Uttarakhand.

\section{REFERENCES}

Abak, K.N., Gürsöz, Y. and Pakyürek, R. (1990). MalçUygulamalarinin Serada Toprak Sicakligi ile Bazi Sebzelerin Verimve Erkencilik Üzerine Etkisi. Türkiye 5. Seracilik Sempozyumu,Izmir. 5:55-62.

Bhatt, L., Rana, R., Uniyal, S.P. and Singh, V.P. (2011). Effect of mulch materials on vegetative characters, yield and economics of summer squash (Cucurbita pepo L.) under rainfed mid - hill condition of Uttarakhand. Veg. Sci. 38(2): 165-168.

Gerber, J.M., Mohd-Khir, I. and Splittoesser, W.E. (1988). Row Tunnel Effects on Growth, Yield and Fruit Quality of Bell Pepper. HortScience, 26(3-4):191-197.

Lodhi, A.S., Kaushal, A. and Singh, K.G. (2013). Effect of irrigation regimes and low tunnel height on microcli- 
matic parameters in growing sweet pepper. International Journal of Engineering Science Invention, 2(7):20-29.

Panse, V.G. and Sukhatme, P. (1989) Statistical methods for Agricultural workers. $3^{\text {rd }}$ edition, ICAR New Delhi, pp 70-99.

Pimpini, F., Granguinto, G., Babbo, G. and Xodo, E. (1987). The Effect of Protective Structures and of Pinching on the Earliness of Table Tomatoes in the Greenhouse. Protte, 16(8/9):63-73.
Salman, S.K., Abou-Hadid, A.F., Beltagy, I.M.J. and Beltagy, A.S. (1992). Plastic House Microclimate as Affected by Low Tunnels and Plastic mulch. Egyptian J. of Hort. 2:111-119.

Singh, B., Kumar, M. and Singh, G.C. (2005). Effect of different plastic mulches on growth and yield of winter tomato. Indian J. Hort. 62(2): 200-202.

Singh, V.P., Singh, P.K. and Bhatt, L. (2014). Use of plastic mulch for enhancing water productivity of off-season vegetables in terraced land in Chamoli district of Uttara- 